\title{
The Problems with Honest and Fairness Principles in General Election in Indonesia
}

\author{
Imawan Sugiharto*, Ratna Riyanti \\ Law Study Program \\ Universitas Pancasakti Tegal \\ Tegal, Indonesia \\ *imawan.sugiharto57@gmail.com
}

\begin{abstract}
Article 22 paragraph (1) of the Constitution of the Republic of Indonesia Year 1945 stated that the General Election is carried out on a direct, open, public, secret, honest and fair manner every five years. This so-called Luber Jurdil (langsung [direct], umum [public], bebas [free], rahasia [secret], jujur [honest] and adil [fair]) general election principle could create an increasingly high-quality general election process in Indonesia since this general election should be viewed as a means for safeguarding the people's sovereignty. This study is aimed at revealing some problems found relating to honest and fairness principles in general election in Indonesia. This is a descriptive qualitative based on library research. The data were grounded from the existing related articles, books, and documents. The data were then analysed deeply related to the subject matter. The problems found that Issues occurred in the implementation of general elections in Indonesia, ranging from money politic to mass mobilization, bureaucracy politicization, unprofessional general election administrators and many others. Such values as dishonesty and unfairness were often observed from either the contestants or administrators of general elections. However, they were never completely dealt with, and they eventually injured the democracy. It was counterproductive considering that the necessity to maintain morality, integrity and capability by both the general election contestants and administrators was the key to a successful and better quality general election.
\end{abstract}

Keywords: general election, honest and fairness principles

\section{INTRODUCTION}

General election is a process of electing someone the filler of certain political offices, ranging from the president, people's representatives in various governmental bodies to a village chief. Another definition of general election is an attempt to influence the people persuasively (rather than forcibly) by performing rhetorical activities, political relations, mass communication, lobbies and so on. It is a mechanism to select and delegate or assign the sovereignty to a person and a party they have their trust in.

Article 22 Paragraph (1) of the 1945 Constitution of the Republic Indonesia states that "General election is carried in a direct, public, free, secret, honest and fair manner every five years. Once upheld, this so-called Luber Jurdil (langsung [direct], umum [public], bebas [free], rahasia [secret], jujur [honest] and adil [fair]) general election principle could create an increasingly high-quality general election process in
Indonesia since this general election should be viewed as a means for safeguarding the people's sovereignty. These principles can only be realized if the administrators of general election and stakeholders have a good will and the public participate in safeguarding the people's voices.

While in practice the general election has been organized well so far in terms of its stages, yet the truth is that it has not been implemented democratically. In particular, when we speak about the honesty and fairness principles, it is not organized well by the general election administrators and participants and even the voters. The various fraud indications such as money politic, mass mobilization, bureaucracy politicization, law enforcer's and general election administrators' non-neutrality, have rendered the general election in Indonesia undemocratic and non-capable. It was counterproductive considering that the necessity to maintain morality, integrity and capability by both the general election contestants and administrators was the key to maintain the general election quality.

Honesty and fairness are the basic principles in organizing a general election. This means the absence of this principles will lead to the invalid governance of the country. Theoretically, honesty is the principle which unites the nation and serves as the foundation and basic pillars of agreement in managing our common life. It is this honesty principle in the general election implementation which serves to ensure the common agreement in managing the life as a nation and a country. With this honesty, we, Indonesians, as a nation could eradicate the prejudice to each other [1].

Furthermore, fairness is the fundamental principle which cannot be separated from the honesty principle. It is a principle which serves as the direction and goal in the organization of general election. Normatively, fairness is the highest element of law [2].

The term fair and fairness are tightly related to all definitions of equal and equality, balanced and balance, reasonable and reasonability, equilibrated and equilibrium, comparable and comparability. Even within the mind of Muslims in Indonesia and elsewhere, fairness is generally related to the definition of placing something to where it belongs, or giving others the same or equivalent treatments [2]. 


\section{A. General Election and Democracy}

Democracy, which was initially born during the Ancient Greek time, has developed rapidly so far. The democracy people currently know is the constitutional democracy. This constitutional democracy is specifically characterized, according to Miriam Budiardjo, by the idea that a democratic government is the one with limited power and it is unjustifiable for them to act arbitrarily to its people. The limitations of this government's power are set forth in the constitution, therefore it is frequently referred to as the constitution-based government [3].

The constitution also regulates on how the government is formed and it is usually done through a general election which is organized on a regular basis in every country. When the general election is organized democratically, it is expected that a legitimate and capable government would be born just as what the entire country are wishing for.

Arora and Awasthy as quoted by Gaffar suggest that general election is tightly related with a state and democracy. The essence of democracy is to involve the people in establishing and managing the government through such activities as participation, representation and monitoring [4].

A modern democracy state is the one implementing the representative democracy. In this representative democracy, the people's rights are exercised by their representative, both those at the legislative and executive bodies. Therefore, these people's representatives should be elected by the people themselves through a general election. Especially, in a democracy state, the role of a representative body which also occupies the position of a legislative body has been increasingly important, particularly in formulating the law and making decisions regarding the state's policies [5]

Various systems of general election have been known so far and each country adopts one of these general election systems to match their respective condition, including Indonesia.

In most democracy countries, general election is considered as a symbol and at the same time a benchmark of that very democracy. The result of general election organized in an open atmosphere with the freedom of speech and association is considered to have reflected accurately the participation and aspiration of the society [2].

\section{B. General Election in Indonesia}

One of the main pillars in every democracy system is a mechanism of channelling the people's voice periodically through a general election organized on a regular basis. The importance of organizing a general election periodically stems from some reasons. Firstly, people's opinions or aspirations regarding aspects of their common life are dynamic in nature from time to time. Within a certain period of time, it is possible for some people to have different opinions on an issue from what they used to have; Secondly, in addition to the people's constantly changing opinions from time to time, people's common life in the society also changes as a result of the international dynamic or domestic factors [6].
Since the Independence Proclamation on August 17, 1945 several general elections have been administered in Indonesia. How these general elections in our country were implemented and carried out keep on changing following the democracy demands. For the first, Indonesia administered a general election in 1955. During the new order government period, the first general election was carried out in 1971 and then in 1978, 1983, 1988, 1992 and finally in 1997. The reform movement in 1998 had brought various changes, particularly in the state administration. One of the impacts of this reform movement was the amendment to the 1945 Constitution. Furthermore, it also influenced the way the general election was carried out which was, of course, substantially different from the general elections administered during the new order reign, both in terms of its system, administrators and even the participants of that general election itself.

After the new order era, Indonesia's general election system had experienced some shifts. The general election system followed in Indonesia is the one which is carried in stages, including the legislative general election, presidential general election and regional head general election. Such separation of general election in stages is deemed less effective and efficient in the implementation of a general election for a country which follows a presidential government system. This is because such a system creates various problems, such as ongoing conflict of interests between groups and individuals, wasting budgets in its implementation, massive money politic, bureaucracy politicization and high intensity of general election in Indonesia and in turn they lead to the low participation of society as a result of public saturation [7].

Taking these considerations into account, as of 2019 simultaneous elections have been organized in legislative elections to elect members of People's Consultative Assembly, People's Representative Council and Regional Representative Council and executive elections to elect President and Vice President.

\section{Methodology}

This work was derived from the phenomenon happening in the society regarding the general election in Indonesia after the reform era. It was found that many problems occurred during the election regarding the honesty and fairness principles. This is a descriptive qualitative based on library research. The data were grounded from the existing related articles, books, and documents. The data were then analysed deeply related to the subject matter.

\section{RESULTS AND DISCUSSION}

\section{A. Honest and Fair Principles in General Election}

General elections have been repeatedly administered in Indonesia by upholding the direct, public, free, secret principles during the new order government periodically once every five years. Nevertheless, it could be said that the general elections during the new order era were the ones full of political manipulations and intrigues along with intimidation to make the government party, i.e. Golongan Karya (Functional Group), a winner despite its refusal of being called as a party. 
Furthermore, during the current reform era, in addition to the initial direct, public, free, and secret principles, two other principles are also added.

The attempt to improve the quality of general election after the new order era has been made. Regulations are prepared from amendment to the laws on General Election, Political Party, Structure and Membership of MPR, DPR, DPD and DPRD, Presidential and Vice Presidential Election and on Regional Government and finally by establishing a law on Gubernatorial, Regent and Mayor Election.

While many regulations have been made, one thing about the general election principles is still kept, namely: the direct, public, free, secret, honest and fair principles are maintained in each of these regulations. To the direct, public, free, and secret principles, nothing needs to be questioned. There is no longer any direction nor pressure, particularly from the government to win a certain party or pair in a general election, especially to the voters. This is significantly different from the general election during the new order era. Nevertheless, to the honest and fair principles, even until recently to what extent these principles are implemented by both the general election administrators in particular and general election contestants in general is still unknown. The conception of democracy and general election was born from the great conception and notion which refer to John Locke and Rousseau, i.e. the freedom assurance, fairness and equality for individuals in all fields. In democracy, participatory and dignity values should be upheld and implemented by citizens and the state's instruments at both legislative, executive and judicative levels. The society need to be provided with a room to actively engage with and take part of a democracy process [8]

Based on the Universal Declaration on Democracy adopted by the Inter-Parliamentary, any general election organized to implement democracy should meet several principles, namely: free, fair, periodic, public, equal and secret. Additionally, respect should be paid to the rights to vote and to be voted, freedom of expression and assembly, access to information, and freedom of association [4].

The 1945 Constitution of the Republic of Indonesia has explicitly mandated these honesty and fairness principles in the organization of each general election. This has been the issue which has occurred so far and never been dealt with by the general election administrators while it is expected that they can contribute to manifest these principles in the organization of each general election.

Under the Law Number 7 Year 2017 concerning General Election, it is stated that the honest principle means all parties related to the general election are obliged to behave honestly according to the applicable regulations. Meanwhile, the term fair means or is defined as equal treatment given to the boters and general election participants alike, free from any fraud of any party whatsoever.

The commonly-found and no-longer-a-secret practice during every general election is indication of frauds committed by both the general election participants and administrators. This is because every time a general election is elected, such phenomena as money politic, bureaucracy politicization, power abuse and regional/state budget misuse, non-neutral genera election administrators and many more fraudulent indications keep on occurring, resulting in the low-quality and less capable general election results. According to Zuhro, the general election in the democracy context is intended none other than to produce an effective government. Meanwhile, one the crucial issues of the 2019 presidential election is bureaucracy politicization. The problem here is how to make the bureaucracy remain professional, independent and politically neutral. It must be admitted that bureaucracy is highly vulnerable to being used as a tool for political interests. When bureaucracy sides with a certain political power, it will create a certain vulnerability [9].

The honest and fair principles in the practice of many general election including legislative, presidential and vice presidential and even regional and village head general elections, are still far from what the justice seekers and particularly the general election contestants themselves expect. The blooming money politic practices which have never been completely dealt with or dealt with in a compromising manner, had no deterrent effect whatsoever to the perpetrators. While it is a fact that a legal process is done against the money politic perpetrators, its percentage is highly insignificant and even nearly unheard of. Meanwhile, non-neutral bureaucracy which is usually used to serve the incumbent's political interests in both regional head and presidential and vice presidential elections can still be found even until now.

It is the dream of every citizen of Indonesia to have a highquality, honest and trustworthy leaders and it is expected that they will bring about changes to this country to the betterment and advancement than its current state. How can it be achieved if even during their elections many improper values and measures are done by those candidates to assume the people's sovereignty. Article 1 paragraph (2) of the 1945 Constitution of the Republic of Indonesia states that: "The sovereignty is in people's hands and it shall be exercised under the Constitution.

The sovereignty being in people's hands, according to Teguh Prasetyo, means that people have the sovereignty, responsibilities, rights and obligations to democratically elect the leaders who will establish a government to manage and serve all of them, and elect their representatives to supervise how the government is managed [10]

The dishonest and unfair methods are even shown blatantly by the incumbents in both regional head and presidential and vice presidential elections, including the misuse of state's fund in the form of state/regional budgets, misuse of government programs, politicization of bureaucracy and State/Regionowned Enterprises, non-neutrality of general election administrators and so forth. All these methods have been done, particularly by incumbents to maintain their succession. Those incumbents are still unsure whether or not they will be reelected for another 5 (five) years to come, and thus and it is no longer a secret that they use unethical ways which contradict the pillars of a good governance principle.

Neither good will nor bravery is shown by the General Election Supervisory Agency and even the General Election Commission to justify their participation. It is counterproductive when they are actually given a strict authority by 
the General Election Law. This means both the General Election Supervisory Agency and the General Election Commission are authorized to sanction the general election contestants if they found to commit any offense, both administrative and criminal ones. In reality, however, all offenses are settled in a compromising way in order to ensure that the general election is organized smoothly. That is the slogan which keeps on occurring in every general election. Had the General Election Supervisory Agency or the General Election Commission been a little bit braver and more decisive in sanction them, both the administrative and criminal offenders of general election, their decisions would undoubtedly be a good precedence and reference for general election contestants to refrain themselves from using unethical and even unlawful methods.

The facts show that many state officials, be it members of legislative and executive boards, have to deal with legal processes and are involved in corruption cases. From one year to another, the number is not decreasing, rather their number keeps on increasing. The Caught-Red-Handed Operation or Operasi Tangkap Tangan (OTT) performed by the Corruption Eradication Commissions receives massive appreciations from the society, serving as an indicator that the perpetrator is suspected to have abuse their power while being the state officials. This actually cannot be separated from the main factors when they enrol as a general election contestant, both for legislative and executive boards. There has been this misleading assumption that they have to get the amount they have spent for their candidacy. It is this misleading assumption which makes the perpetrators to use their authority for improper purposes or to use the state funds for their personal or group interests.

\section{CONCLUSION}

The absence of political desire and seriousness in this nation, particularly in the general election contestants and administrators in observing alleged frauds in every stage of general election has made it impossible to apply the honest and fair principles optimally. The honest and fair principles will forever be merely an ornament and meaningless words, written in the general election regulations yet extremely difficult to be the paradigm of democratic general election pride. It is only this nation who know when will such a sorry state of affairs end. While being fully aware that general election requires significant amount of energy and budget, in practice it only gives birth to low-quality or even quality less leaders of oligarchic nature.

\section{REFERENCES}

[1] B. Widjojanto and D. Indrayana, Permohonan Perselisihan Hasi Pemilihan Umum Presiden dan Wakil Presiden [Online]. Retreived from: https://mkri.id, 2019.

[2] J. Asshiddhiqie, Konstitusi Keadilan Sosial. Jakarta: Kompas, 2018.

[3] M. Budiardjo, Pengantar Ilmu Politik. Jakarta: Gramedia Pustaka Utama, 2012.

[4] M.J. Gaffar, Demokrasi dan Pemilu Indonesia. Jakarta: Constitution Press, 2013

[5] M.M.D. Mahfud, Hukum dan Pilar-Pilar Demokrasi. Yogyakarta: Gama Media, 1999.

[6] J. Asshidiqie, Pokok-Pokok Hukum Tata Negara Indonesia Pasca Reformasi. Jakarta: Bhuana Ilmu Populer, 2008.

[7] R. Solihah, "Peluang dan Tantangan Pemilu Serentak 2019 Dalam Perspektif Politik," Jurnal Ilmiah Ilmu Pemerintahan, vol. 3, no. 1, 2018.

[8] F.R. Bachtiar, "Pemilu Indonesia: Kiblat Negara Demokrasi dari Berbagai Refresentasi,” JPP (Jurnal Politik Profetik), vol. 2, no. 1, 2014.

[9] S. Zuhro, "Demokrasi dan Pemilu Presiden," Jurnal Politik Profetik, vol 16, no. 1, 2019

[10] T. Prasetyo, Pemilu Bermartabat (Reorientasi Pemikiran Baru Tentang Pemilu). Depok: Raja Grafindo Persada, 2017. 